https://doi.org/10.11646/palaeoentomology.3.6.1

http://zoobank.org/urn:lsid:zoobank.org:pub:4DD6E9D8-FC98-4736-B42C-CB94AE48E644

\title{
First argiolestid damselfly (Odonata: Zygoptera) from the late Palaeocene of Northwest Argentina
}

\author{
JULIÁN F. PETRULEVIČIUS \\ CONICET - División Paleozoología Invertebrados, Facultad de Ciencias Naturales y Museo, Universidad Nacional de La Plata, Paseo \\ del Bosque s/n, La Plata (1900), Argentina \\ ”levicius@fcnym.unlp.edu.ar; ○https://orcid.org/0000-0003-4529-9555
}

Megapodagrionids in the wide sense are a polyphyletic group of damselflies (Huang et al., 2018). In recent studies there is a tendency to restrict the Megapodagrionidae only to few genera, and to over rank some subfamilies such as Philosininae and Argiolestinae to family level (Kalkman \& Theischinger, 2013; Dijkstra et al., 2014). These efforts are based on nymphal (Kalkman et al., 2010) and wing characters (Kalkman \& Theischinger, 2013).

Megapodagrionids (sensu lato) are common in the fossil record mainly represented by isolated wings. This renders difficult their study because there is not yet a well solved classification and after the study of Bechly (2007) there are few discovered characters on wing venation, many of which are convergences. The group was in the fossil record of South America absent up to now, but it is represented in the Cenozoic of North America (Cockerell, 1907, 1921; Scudder, 1890) and Europe (Azar \& Nel, 2008; Nel et al., 1997; Petrulevičius et al., 2008), and the Cretaceous of Asia (Huang et al., 2018).

Recent megapodagrionids sensu lato have a nearly cosmopolitan distribution, being absent from North America (Kalkman, 2013). Recent species of Argiolestidae inhabit the African, Oriental, and Australian regions (Kalkman \& Theischinger, 2013). Here I describe the first Argiolestidae recorded in America, from the late Palaeocene of Maíz Gordo Formation in Northwest Argentina.

\section{Material and methods}

The specimen is housed at the División Paleozoología Invertebrados, Museo de La Plata, La Plata, Argentina (acronym MLP). The specimen was originally partly covered, and was prepared with a pneumatic hammer.

In this work, I follow the wing venation nomenclature of Kukalová-Peck (1983), amended by Kukalová-Peck (1991, 2009), also contributions by Riek \& Kukalová-Peck (1984), Nel et al. (1993), Bechly (1996), and Petrulevičius \& Gutiérrez (2016). The higher classification of fossil and extant Odonata is based on the phylogenetic system of Bechly (1996, 2007).

\section{Systematic palaeontology}

Odonata Fabricius, 1793

Euzygoptera Bechly, 1996

Argiolestidae Fraser, 1957

Argiolestinae Fraser, 1957

\section{Genus Librelula gen. nov.}

Type species. Librelula maradoniana sp. nov.

Etymology. Wordplay from Castilian words libélula, meaning Odonata, and libre, meaning free; Lula.

Diagnosis. (1) pterostigma relatively shortened; (2) tendency to alignment of crossveins; (3) bases of veins RP3/4 and IR2 between levels of nodus and subnodus; (4) branches of RP diverging distally (supplementary sectors); (5) cubital area with two rows of cells; (6) supplementary sectors between medial veins; (7) pterostigma covering three and a half cells; (8) IR2 originating one and a half cells basal to subnodus; (9) distal side of discoidal cell less than twice basal side; (10) $\mathrm{CuP}+\mathrm{AA}$ emerging from wing margin basal to Ax2; (11) RP3/4 reaching level of pterostigma.

Characters 1-3 present in Coenagrionomorpha Bechly (2007). Character 4 present in Argiolestinae sensu Bechly (2007). Character 5 present in some Argiolestinae sensu Kalkman \& Theischinger (2013). The combination of characters 6 to 11 is unique.

\section{Librelula maradoniana sp. nov.}

(Figs 1, 2)

Holotype. MLP 29425. Argentina, province of Jujuy, El Fuerte, latitude $24^{\circ} 20^{\prime} \mathrm{S}$, longitude $64^{\circ} 28^{\prime} \mathrm{W}$, green shales, Maíz Gordo Formation, Late Palaeocene (Volkheimer et al., 1984; Quattrocchio et al., 1997). 

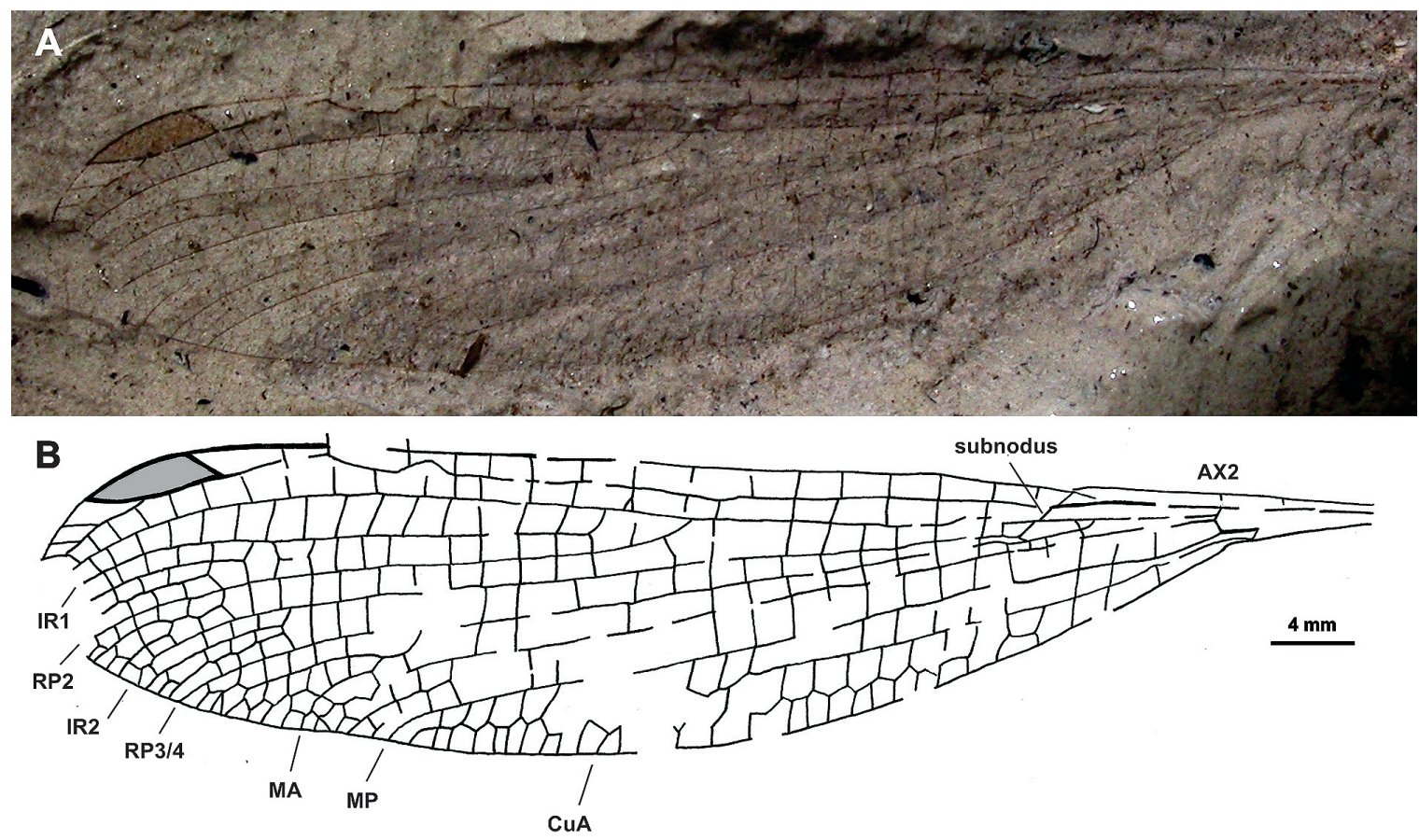

FIGURE 1. Habitus of Librelula maradoniana gen. et sp. nov., holotype MLP 29425 from El Fuerte (Jujuy, Argentina); late Palaeocene. A, Photograph. B, Camera lucida drawing.

Etymology. In honour to Diego Armando Maradona (El Diego) the best world football player ever. In 1986 FIFA World Cup, Maradona, the "People football player", redefined the football in less than five minutes (https:// edition.cnn.com/2018/06/11/football/world-cup-argentinaengland-1986-diego-maradona/index.html), first with the "hand of God" goal and then with "the goal of the Century", related exquisitely by Victor Hugo Morales. In words of Emir Kusturica (https://www.youtube.com/watch?v=O8G9ytZgbM) "that match was maybe the first and the last time that there was justice in the world". He inspired the people and many popular artistic expressions via his Maradonian way.

Diagnosis. As for the genus (vide supra).

Type locality and horizon. Maíz Gordo Formation, El Fuerte, Jujuy province, Argentina; Late Palaeocene.

Description. Wing hyaline, length $30 \mathrm{~mm}$; max. width $6.6 \mathrm{~mm}$; distance between nodus and pterostigma $18.8 \mathrm{~mm}$; distance from base to nodus $6.8 \mathrm{~mm}$ (nodus situated at about $20 \%$ of wing length); from pterostigma to wing apex 1.85 $\mathrm{mm}$; distance from base to arculus $3.5 \mathrm{~mm}$; Ax1 and Ax2 well defined; Ax1 $1.4 \mathrm{~mm}$ basal to arculus; no secondary antenodal crossveins; $16-17$ postnodal crossveins between nodus and pterostigma, 18 corresponding postsubnodal crossveins; postnodal and postsubnodal crossveins rather well-aligned (12); pterostigma $3 \mathrm{~mm}$ long and max. $0.8 \mathrm{~mm}$ wide, not braced and covering three and a half cells; basal side of pterostigma slightly oblique, distal side very slanted; three preserved crossveins distal to pterostigma between $\mathrm{C}$ and RA; arculus aligned with Ax2; posterior part of arculus (basal discoidal crossvein) forming a discoidal cell basally closed, trapezoidal and free of crossveins; posterior margin of discoidal cell $(\mathrm{MP}+\mathrm{CuA})$ aligned with $\mathrm{MP}$, and $\mathrm{CuA}$ kinked becoming slightly bended posteriorly with distal part zigzagged; origins of RP and MA approximate in arculus; $\mathrm{CuP}$ crossing $0.7 \mathrm{~mm}$ basal to arculus, where emerge $\mathrm{CuP}+\mathrm{AA}$; two rows of cells between $\mathrm{CuA}$ and wing margin; nodal $\mathrm{Cr}$ and subnodus very oblique; MP nearly straight, slightly concave posteriorly; MA barely zigzagged and ending three cells basal to pterostigma; RP3/4 $1.1 \mathrm{~mm}$ (two cells) basal to subnodus; IR2 just distal to subnodus; RP2 $8 \mathrm{~mm}$ and ten cells distal to subnodus; no lestine oblique vein ' $\mathrm{O}$ '; two rows of cells between MP and MA four cells before ending; nine rows of cells at wing margin from MA to RP3/4; two longitudinal veins seven rows before wing margin between MA to RP3/4; two longitudinal veins five rows before wing margin between RP3/4 to IR2; two longitudinal veins four rows before wing margin between IR2 to RP2; two longitudinal veins seven rows before wing margin between RP2 to IR1; space between IR1 and RP1 narrowing from level of pterostigma to wing margin.

\section{Discussion}

The affinities of this damselfly are rather tricky to establish. At first sight it shows a general habitus similar to different groups of far affinities. In this sense, its attribution to the Dysagrionidae is unlikely because it lacks the main diagnostic characters of this family, i.e., a distinct broadening of antenodal area at level of primary antenodal brackets, and a rectangular 

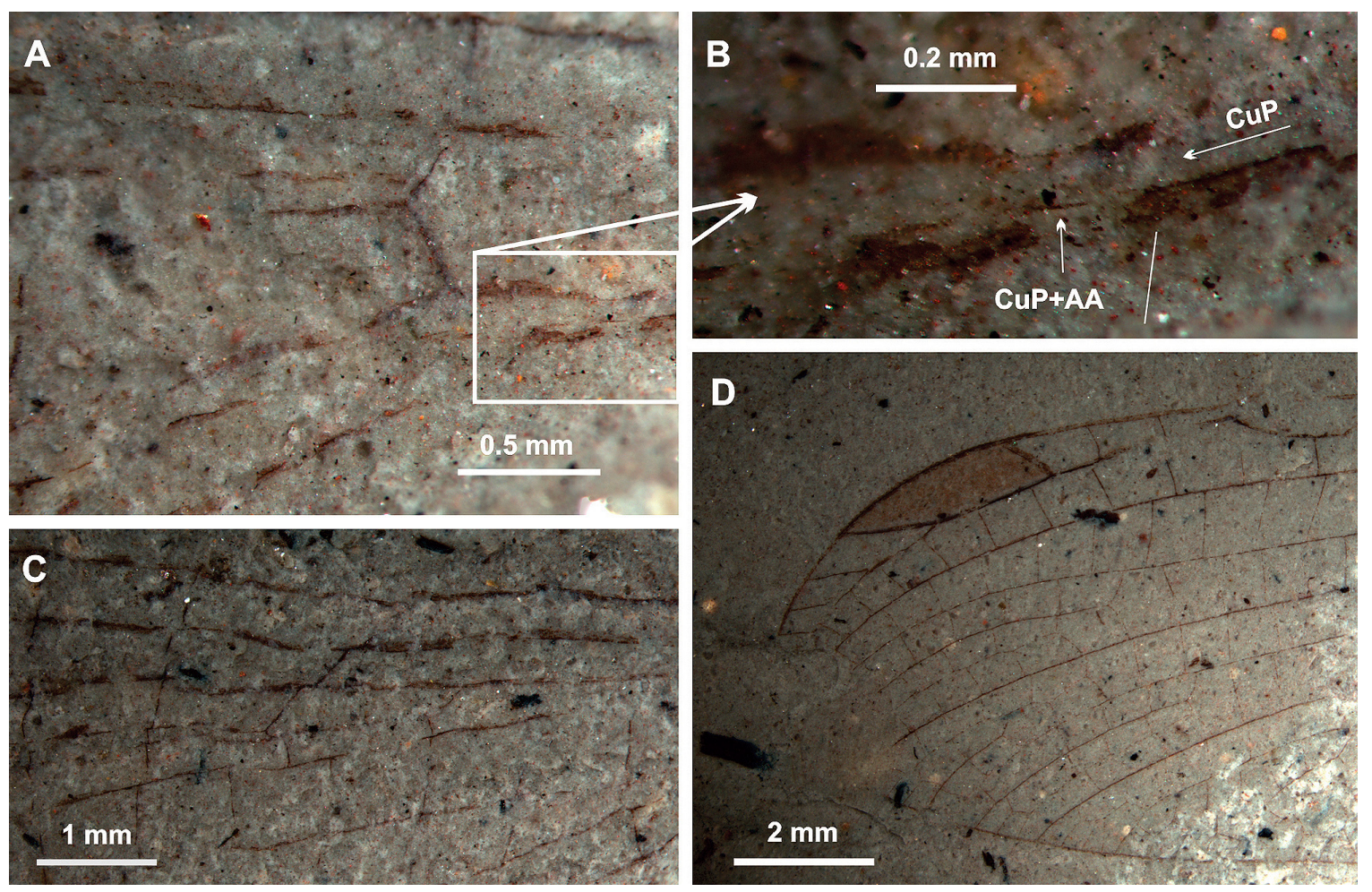

FIGURE 2. Details of the wing of Librelula maradoniana gen. et sp. nov., Holotype MLP 29425 from El Fuerte (Jujuy, Argentina); late Palaeocene. A, Arculus. B, Emergence of CuP+AA. C, Nodus. D, Pterostigma.

discoidal cell with distal side directed towards wing base, perpendicular to anterior side. The absence of oblique crossvein ' $\mathrm{O}$ ', pterostigma relatively shortened, tendency to alignment of crossveins, and bases of veins RP3/4 and IR2 between levels of nodus and subnodus, strongly suggest affinities with Coenagrionomorpha Bechly, 1996. Within the Coenagrionomorpha, the Hypolestidae could be excluded because of their amphipterygid type of pterostigma (basal margin strongly slanting). The Coenagrioniformia Bechly, 1996 could also be excluded because of their intercalary veins (except IR1 and IR2) suppressed and presence of only two rows of cells in the total wing space between RP1 and RP2, which are separated by IR1. The last group within the Coenagriomorpha are the Megapodagrionidae sensu Bechly (2007). The Megapodagrionidae sensu lato is considered a polyphyletic group by recent authors (Bybee et al., 2008; Dumont et al., 2009; Rehn, 2003). Bechly (2007) restricted the family to two subfamilies, Megapodagrioninae and Argiolestinae including the genera listed in Bridges (1994). This group do not have any known synapomorphies in the wing venation after Bechly $(1998,2007)$. The Argiolestinae sensu Bechly (2007) have the longitudinal wing veins curved, thus somewhat shortened (especially MA, MP and $\mathrm{CuA}$ ); the branches of RP distally diverging (reversal); and more than one row of cells between $\mathrm{CuA}$ and the hind margin (reversal). Kalkman \& Theischinger (2013) redefined this group and gave it a family rank. The Argiolestidae sensu Kalkman \& Theischinger (2013) included 20 genera in this family.
Wing characters sensu these authors are: (1) two, seldom three Ax; (2) supplementary sectors between IR1 and RP2 and between RP2 and IR2 present; (3) pterostigma longer than broad (except in Caledargiolestes Kennedy, 1925); and (4) IR2 originating near subnodus, starting clearly closer to nodus than to arculus. Our specimen could be attributed to this group by sharing some characters postulated by Bechly (2007) and those by Kalkman \& Theischinger (2013). The studied specimen has the longitudinal wing veins somewhat straight and not too much curved as stated by Bechly (2007) for the Argiolestinae. Some of the genera of Argiolestidae: Argiolestinae sensu Kalkman \& Theischinger (2013) like Wahnesia Förster, 1900, Trineuragrion Ris, 1915 and Pyrrhargiolestes Kalkman \& Theischinger, 2013 have the longitudinal veins somewhat straight. Kalkman \& Theischinger (2013) divided the family into Argiolestinae and Podolestinae. The Podolestinae could be excluded because they have the cubital area with only one row of cells. The Argiolestinae include genera with one, two, three, even more rows of cells in the cubital area. The studied specimen differs from all these genera by having the base of $\mathrm{CuP}+\mathrm{AA}$ well basal to the discoidal cell and basal to Ax2. Miniargiolestes Theischinger, 1998 has the base of $\mathrm{CuP}+\mathrm{AA}$ just basal to the $\mathrm{Ax} 2$ in the hind wing but differs in other several characters as the shape of the discoidal cell, only two cells between discoidal cell and RP3+4, few (5-6) crossveins from RP2 to IR1 (contra ten), and the shorter pterostigma covering two and a half cells (contra three and a half). Some Podolestinae 
such as Podolestes Selys, 1862 share with the studied specimen the base of $\mathrm{CuP}+\mathrm{AA}$ basal to the arculus. The new species has also the distal side of the discoidal cell barely oblique, another unique character among the extant genera of Argiolestidae. Amanipodagrion Pinhey, 1962 (excluded from the family by Kalkman \& Theischinger, 2013) has a similar discoidal cell but differs in having the $\mathrm{CuP}+\mathrm{AA}$ in a very distal position, subnodus straight and the RP at the level of the distal part of the discoidal cell (contra two cells distal).

Fossil genera of Megapodagrionidae sensu lato could be excluded: Eckfeldia Petrulevičius et al., 2008 (Petrulevičius et al., 2008) because of its pterostigmal brace, pterostigma short, one row of cells in cubital area, $\mathrm{CuP}$ proximal to the arculus and distal to the base of $\mathrm{CuP}+\mathrm{AA}$, and broader and shorter wing; Furagrion Petrulevičius et al., 2008 because of its CuP proximal of the arculus and distal to the base of $\mathrm{CuP}+\mathrm{AA}$, discoidal cell shorter and with a more oblique distal side, few (five) crossveins from RP2 to IR1 (contra nine), and nodus and subnodus vertical (contra oblique); Eopodagrion Cockerell, 1920 because of its very oblique pterostigmal brace, subnodus almost vertical, shape of discoidal and subdiscoidal cells, and less numerous postdiscoidal crossveins (11 instead of 18 in the new species) (Cockerell, 1920); Melanagrion Cockerell, 1907 because of its two rows of cells in the area between C and RA distal to the pterostigma, and pterostigma with five cells below (contra three) (Cockerell, 1907, Petrulevičius et al., 2008); Miopodagrion Kennedy, 1925 because of its two rows of cells in the area between $\mathrm{C}$ and RA distal to the pterostigma, nodus with different habitus, distal side of discoidal cell more oblique and more than twice the basal side (contra less than twice the basal side) and distal part of wings dusky; Vulcagrion Nel \& Paicheler, 1994 because of the IR2 and RP3/4 fused basally distal to the subnodus, base of $\mathrm{CuP}+\mathrm{AA}$ very distal and wing petiolate distally to CuP (same for Lithagrion Scudder, 1890); Oligoargiolestes Kennedy, 1925 because its pterostigma covers less than two cells and it has a more oblique distal side (Nel, unpublished data; Petrulevičius et al., 2008); Cerdanyagrion Nel, Arillo \& Martínez-Delclòs, 1996 because it has a double row of cells in the areas between RA and RP1 and C and RA (Nel et al., 1996); Thanetophilosina Nel et al. 1997 because it has considerably more postnodal crossveins (30 contra 19), the base of RP2 is in a distinctly more basal position, only six cells distal of subnodus (contra nine) (Nel et al., 1997) and the pterostigma with eight cells beneath (contra three); Electropodragrion Azar \& Nel, 2008 because it has one row of cells between $\mathrm{CuA}$ and wing margin, less development of secondary longitudinal veins, and distal side of discoidal cell more oblique; Cretapodagrion Huang et al., 2018 because of one row of cells between $\mathrm{CuA}$ and wing margin, distal side of discoidal cell more oblique, and the base of RP2 in a more basal position, four cells distal to subnodus (contra nine).

\section{Conclusion}

The specimen is treated as a new genus and species Librelula maradoniana gen. et sp. nov. based on a unique combination of characters with respect to the genera of 'Megapodagrionidae' sensu lato (that includes the family Argiolestidae) i.e., supplementary sectors between IR1 and RP2 and between RP2 and IR2; pterostigma covering three and a half cells; IR2 originating one and a half cells basal to subnodus; two rows of cells between $\mathrm{CuA}$ and hind margin; distal side of the discoidal cell less than twice the basal side; $\mathrm{CuP}+\mathrm{AA}$ emerging from wing margin basal to Ax2; RP 3/4 reaching level of pterostigma.

The new genus coincides with its wing venation characters to those of the Argiolestidae sensu Kalkman \& Theischinger (2013). Within Argiolestidae, it has similarities with Argiolestinae, but new material could help to establish these relationships more accurately. If assumed as an Argiolestidae sensu Kalkman \& Theischinger (2013) the new species represents the first species in the New World. The two subfamilies of Argiolestidae are distributed on either side of the Huxley line (Kalkman \& Theischinger, 2013). The Podolestinae from Africa and Madagascar to Malay Peninsula, Borneo, Sumatra and Hainan. The Argiolestinae on the Wallacea side of Luzon, Celebes and New Guinea, New Caledonia, and Australia.

The discovery of a new genus of Argiolestidae: Argiolestinae (?) in the Palaeocene of Northwest Argentina gives a new clue to the biogeographic and phylogenetic history of the family. Its suspected relationships with the subfamily present in Australia could reflect the historical relationships via Antarctica of these continents.

\section{Acknowledgements}

Funding support for lab. studies came from grants: SECyT N875 from the National University of La Plata (UNLP), PIP 0834 from the National Research Council of Argentina (CONICET) and PICT-2016-4297 from the National Agency of Scientific and Technological Promotion of Argentina (ANPCyT). Thanks also to CIMBA.

\section{References}

Azar, D. \& Nel, A. (2008) First Baltic amber megapodagrionid damselfly (Odonata: Zygoptera). Annales de la Société Entomologique de France (N.S.), 44, 451-457. https://doi.org/10.1080/00379271.2008.10697580

Bechly, G. (1996) Morphologische Untersuchungen am Flügelgeäder der rezenten Libellen und deren Stammgruppen- 
vertreter (Insecta; Pterygota; Odonata), unter besonderer Berücksichtigung der Phylogenetischen Systematik und des Grundplanes der Odonata. Petalura, special volume 2, 402 pp. (Revised edition of the 1995 publication, with an English appendix including a new phylogenetic system of fossil and Recent Odonata).

Bechly, G. (2007) Phylogenetic Systematics of Odonata. Available at: https://bechly.lima-city.de/system.htm (Accessed on $14^{\text {th }}$ September 2020).

Cockerell, T.D.A. (1907) Fossil dragonflies from Florissant. Bulletin of the American Museum of Natural History, 23, 133-139.

Cockerell, T.D.A. (1921) Eocene insects from the Rocky Mountains. Proceedings of the United States National Museum, 57, 233-260. https://doi.org/10.5479/si.00963801.57-2313.233

Dijkstra, K.-D.B., Kalkman, V.J., Dow, R.A., Stokvis, F.R. \& Van Tol, J. (2014) Redefining the damselfly families: a comprehensive molecular phylogeny of Zygoptera (Odonata). Systematic Entomology, 39, 68-96. https://doi.org/10.1111/syen.12035

Huang, D.Y., Azar, D. \& Nel. A. (2018) The oldest 'Megapodagrionidae' (Odonata, Zygoptera) discovered in the Lower Cretaceous Yixian Formation, China. Cretaceous Research, 84, 426-430.

https://doi.org/10.1016/j.cretres.2017.12.003

Kalkman, V.J. (2013) Studies on phylogeny and biogeography of damselflies (Odonata) with emphasis on the Argiolestidae. Ph.D. Thesis, Leiden University, 224 pp.

Kalkman, V.J. \& Theischinger, G. (2013) Generic revision of Argiolestidae (Odonata), with four new genera. International Journal of Odonatology, 16, 1-52. https://doi.org/10.1080/13887890.2012.749450

Kalkman, V.J., Choong, C.Y., Orr, A.G. \& Schütte, K. (2010) Remarks on the taxonomy of Megapodagrionidae with emphasis on the larval gills (Odonata). International Journal of Odonatology, 13, 119-135.

Kukalová-Peck, J. (1983) Origin of the insect wing and wing articulation from the arthropodan leg. Canadian Journal of Zoology, 61, 1618-1669. https://doi.org/10.1139/z83-217

Kukalová-Peck, J. (1991) Fossil history and the evolution of hexapod structures. In: Naumann, I.D. (Ed.). The insects of
Australia: A textbook for students and research workers, Volume 1. $2^{\text {nd }}$ ed. Melbourne University Press, Melbourne, pp. 141-179.

Nel, A., Martínez-Delclòs, X., Papier, F. \& Oudard, J. (1997) New Tertiary fossil Odonata from France. (Sieblosiidae, Lestidae, Coenagrioniidae, Megapodagrionidae, Libellulidae). Deutsche Entomologische Zeitschrift, 44, 231-258. https://doi.org/10.1002/mmnd.19970440210

Petrulevičius, J.F. (2001a) Cenozoic insects from Argentina. Biogeographical aspects. Proceedings of the First International Meeting on Paleoarthropodology. Acta Geologica Leopoldensia, 24, 137-144.

Petrulevičius, J.F. (2001b) Insectos del Paleógeno del Noroeste de la Argentina. Sistemática, tafonomía y paleosinecología. Ph.D. Thesis, Universidad Nacional de La Plata, La Plata, $229 \mathrm{pp}$.

Petrulevičius, J.F. \& Gutiérrez, P.R. (2016) New basal Odonatoptera (Insecta) from the lower Carboniferous (Serpukhovian) of Argentina. Arquivos Entomolóxicos, 16, 341-358.

Petrulevičius, J.F., Wappler, T., Wedmann, S., Rust, J. \& Nel, A. (2008) New megapodagrionid damselflies (Odonata: Zygoptera) from the Paleogene of Europe. Journal of Paleontology, 82, 1173-1181. https://doi.org/10.1666/07-091.1

Quattrocchio, M., Volkheimer, W. \& Del Papa, C.E. (1997) Palynology and paleoenvironment of the "Faja Gris" Mealla Formation (Salta Group) at Garabatal Creek (NW Argentina). Palynology, 21, 231-247. https://doi.org/10.1080/01916122.1997.9989498

Riek, E.F. \& Kukalová-Peck, J. (1984) A new interpretation of dragonfly wing venation based upon early Carboniferous fossils from Argentina (Insecta: Odonatoidea) and basic character states in pterygote wings. Canadian Journal of Zoology, 62, 1150-1166.

https://doi.org/10.1139/z84-166

Scudder, S.H. (1890) The fossil insects of North America (with notes on some European species). 2. The Tertiary insects. Report of the United States Geological Survey of the Territories, $13,1-734$. https://doi.org/10.5962/bhl.title.39749

Volkheimer, W., Quattrocchio, M. \& Salfity, J.A. (1984) Data palinológicos de la Formación Maíz Gordo, Terciario Inferior de la Cuenca de Salta, Actas del IX Congreso Geológico Argentino, 4, 523-538. 